становище. Позиція Азербайджану на перетині основних торговельних шляхів вздовж транспортних та енергетичних коридорів Схід-Захід і Північ-Південь, які розвиваються $\epsilon$ важливим активом для перетворення краӥни в центр енергетики та інфраструктури. Враховуючи динамічний сочіально-економічний розвиток, досягнутий за останнє десятиріччя та потенціал майбутнього розвитку, Азербайджанська Республіка вважається найважливішою $і$ найперспективною країною в регіоні. Реалізація нової стратегії нафти та трансначіональних енергетичних транспортних $і$ комунікаційних проектів, закладена президентом Гейдаром Алієвим в 1994 роиі, перетворила Азербайджан на привабливого партнера для провідних держав та компаній світу. Реалізачія проекту «Південний газовий коридор» додасть нових успіхів у реалізацію проекту «Контракт століття» та реалізації проекту Баку-Тбілісі-Джейхан на його основі. Враховуючи всі иі фактори, не випадково регіональні та міжнародні лідери зачікавлені у співпраці з Азербайджаном.

Ключові слова: Азербайджан, політика, енергетика, ЄС, США, нафтові контракти

\author{
УДК 94 (5) \\ http://doi.org/10.17721/2521-1706.2018.04.160-168
}

Farahile Babaeva Shukurova, Research Fellow, Department of Caucasus Policy Institute of the Caucasus Study, Azerbaijan National University Republic of Azerbaijan

\title{
THE KARABAGH CONFLICT IN THE CONTEXT OF THE UNITED STATES' GLOBAL POLICY
}

\begin{abstract}
The aim of the Minsk group of OSCE established on March 1992 was to mediate the peaceful solution of the Armenia-Azerbaijan Nagorno-Karabakh conflict: "From December 1996, the Minsk Group is co-chaired by three states - Russia, the United States and France. But unfortunately the conflict still remains unresolved. Zero progress has been reached so far in the negotiation mediated by the Minsk group. Armenia is not interested in resolution of the conflict. It tends to keep the position of neither fire, nor peace. But in the early April of 2016, as result of subversion of Armenian armed forces the tension in the contact line of troops which was followed by numerous human causalities, once more confirmed that remaining the conflict frozen might would always cause the intense war." But the international mediators for some reason wouldn't demonstrate any unequivocal position upon this case although they support the territorial integrity of Azerbaijan. It is expected that the members of the Minsk group of the OSCE, as well as global community would take precise measures to solve this problem fairly. Failure to adhere to the principle of justice would draw to crisis not only the region, but also worldwide. The reality is that, the USA, Russia and France wouldn't bring the aggressor down as a neither permanent member of the UN SC, nor as a member states. It is a painful and thought-provoking truth, but it is still the case.
\end{abstract}

Key words: conflict, USA, UN, ESCO, politics.

Armenian-Azerbaijan conflict has got deep historical root causes. This process started with the movement of Armenians to the territory of Azerbaijan occupied by Russia at the beginning of the XIX century undergone through the massive terror and genocide of Azerbaijani people in 1905-1906 and 1918-1920. Later on during the Soviet Union period on the basis of the former Azerbaijani lands current Armenian SSR was established by execution of ethnic cleaning against the Azerbaijanis who had been living 
there for centuries. By the decision of the Central Executive Committee of Azerbaijan SSR dated July 7, 1923 the Nagorno-Karabakh autonomous region has been established. By starting repelling the remaining 250 thousands of Azerbaijanis from the Armenia SSR at the end of 1987 in a planned manner the next stage of the conflict was triggered. On $20^{\text {th }}$ February 1988 the decision adopted by the Armenian representatives of the Session of the Regional Council of Nagorno-Karabakh Autonomous Region "About the request to General Assemblies of Azerbaijan SSR and Armenia SSR for the assignment of the NKAR from the Azerbaijan to the Armenian republic" and on the $1^{\text {st }}$ of December 1989 the resolution of the Armenian SSR General Assembly "Remerging the Armenia SSR and Nagorno-Karabakh" was adopted which has still not been cancelled [1].

Current Armenian-Azerbaijani conflict which became even tenser in 1992-1994, got the shape of the large scale military aggression of Armenian republic against the Azerbaijan republic. The occupation of Khojali at the night from $25^{\text {th }}$ to $26^{\text {th }}$ of February 1992 included in the list of the black list of the crimes committed against the humanity during XX century as a specially brutally committed tragedy. In this genocide 613 innocent inhabitants were killed including old people, women and children [2].

After this the Armenian armed forces funded from the abroad occupied Shusha, Khojali, Khijavend, Lachin, Kalbajar, Jabrayil, Kubadli and Zengilan regions and most part of the Agdam region including the center of it, some part of the Fizuli region including its center and the part of Tartar region together with 890 settlements around it which belonged to the former NKAR in 1992-1993, in total about 1/5 part of the Azerbaijani territory and drove all the Azerbaijani population there from their native land. So, as a result of the conflict about 1000000 azerbaijanis became a refugee, 20000 of Azerbaijanis were killed, 50000 of them were wounded or got permanent disability, 5000 of Azerbaijanis were disappeared and Nakhchivan region exposed to the blockade by the Armenian republic [3]. Since $12^{\text {th }}$ of May 1994 ceasefire was achieved between the sides of the Armenian-Azerbaijani conflict.

The Armenian-Azerbaijan conflict didn't attract the attention of the international community for long time. One of the reasons of this was that the world community was not interested on resolving it at the first stage. Because this was recognized as one of the multiple factors to facilitate the collapse of the Soviet Union and its elimination could have hindered the destructive processes within the Soviet Union. It is quite interesting that, the Nagorno-Karabakh conflict triggered by directly Kremlin's scenario. The union administration intended to hinder the expansion of the freedom movements observed in the allied republics by distracting the attention from the main problems of the country by means of creating the regional conflicts based on principle of "separate and rule".

Armenian armed forces had fairly expanded the scale of the operations toward the occupation of the territory of our republic on 1992. However, no international organization objectively estimated this aggression that are in the eyes of everyone and grossly violate international law. It is true that in different periods the UN, ESCO and EU had adopted some resolutions and declarations about it. However these documents didn't estimate the true causes of the conflict and didn't identify the differences between aggressor side and the side which is exposed to the aggression.

After declaring its independency, Azerbaijan Republic called for different organizations such as the UN and world states about that conflict. Azerbaijan became a member of the UN on March 1992 [4]. Later on Azerbaijan requested the UN raise its concern against the aggressor policy of Armenia and stop the occupation actions of this country. The representatives of the UN visited to the region based on this request and 
reported to the Secretary General about the outcome of this visit. The Secretary General on its turn stated that he supports the efforts of ESCO and they are ready to assist it to get the results [5]. It was already the symptoms of cold approach by the international community to this conflict.

Occupation of Shusha on 1992 made Azerbaijan to call for the UN again. On May 12 the UN Security Council satisfied just adopting a declaration after discussion of Karabakh conflict. In the declaration worry is expressed about the situation getting worse in Karabakh and the need for aid to refugees is stated.

In the UN SC resolutions number 822, 853, 874 and 884 about the expansion of the military aggression of Armenia against Azerbaijan and also in the 7 declarations adopted by the chief of the SC the necessity of the security of the territorial integrity, sovereignty and borders of Azerbaijan is stated [6]. Despite it was indicated in the UN SC resolutions that the aggressor forces must immediately leave the occupied territories of Azerbaijan, the power states like the US, France and Russia didn't agree with calling Armenia as an aggressor state and advised to resolve the conflict by means of negotiations and ceasefire.

Thus, the efforts of the UN and world community for resolving AzerbaijanArmenian NK conflict by means of peaceful ways didn't give an effective outcome due to Armenian republic remaining in open aggressor position. The main cause of the unsuccessfulness of the peaceful policy of the UN in the region is not confirming the direct aggression of Armenian republic against the Republic of Azerbaijan.

Despite of the fact that the Republic of Armenia violates the international law principles defined in the $1^{\text {st }}$ and $2^{\text {nd }}$ items of the UN charter and in the Final act of the OSCE, the multiple fact-finding missions of the mentioned prestigious organizations avoid or unwilling to recognize the direct involvement of the Armenian armed forces in the conflict while they make their decisions. However the known resolutions of the UN $\mathrm{SC}$ and the current documents of the other international organizations and the declarations of the chief of the SC reflects the recognition of the involvement of the republic of Armenia in this conflict in some means and aggression factors. And this is an international crime; in the $29^{\text {th }}$ session of the UN GA held in 1974 any kind of the aggression (in direct or indirect way) was declared to be a military crime [7].

The aggression of Armenia against Azerbaijan explicitly violates the norms and principles of international law. So that, as a peacekeeper organization the main function of the UN is mentioned to "Maintain the international peace and to conduct effective and collective measures against the aggressive actions or any other violating actions directed to break the peace" in the $1^{\text {st }}$ paragraph of the $1^{\text {st }}$ item of the UN charter. The charter bans not just aggression, it bans also application of threat or force in interstate relationships (the $2^{\text {nd }}$ paragraph of the $2^{\text {nd }}$ item), requires the peaceful resolution of any kind of conflicts that might happen between states (the $3^{\text {rd }}$ paragraph $\mathrm{f}$ the $2^{\text {nd }}$ item).

The state which have been exposed to aggression raises the issue for the UN SC about requiring the responsibility of the aggressor state according to the $39^{\text {th }}$ item of the UN charter. Even having the mentioned fact in one of the clauses of the notion of the aggression is enough for the UN SC to apply the mandatory actions against the aggressor state according to the $6^{\text {th }}$ and $7^{\text {th }}$ chapter of the Charter. In the UN GA draft resolution number 2330 (XXII) $18^{\text {th }}$ December 1967 prevention of the aggressive actions, maintaining the international peace and security according to the UN charter as well as the meaning of the aggression were reflected to be able to conduct effective measures [8]. All the actions which form the genocide crime identified in that convention have been applied against Azerbaijani people through the aggression of Armenia against 
Azerbaijan. The aggressor policy of this aggressor country has been committed for more than 20 years explicitly in front of the world community.

The documentations adopted by the all international organizations on resolving the conflict by peaceful means also once more say the strengthening the position of Azerbaijan and confirms the resolution of the issue on the basis of the international principles. In this point of view 4 resolutions of the UN SC, decisions of OSCE, European Council and Islamic Cooperation Organization also have importance and they are legal basis for defense of the fair position of Azerbaijan in an international level. But recently in the resolutions adopted in the summits of European Parliament and the UN the territorial integrity of Azerbaijan and stopping the occupation is supported.

For that reason the power nations should take decisive practical measures according to the $7^{\text {th }}$ chapter of the UN Charter and should submit Armenia to the will of international community if they really want to stop the aggression which is dangerous to the modern international relationships.

It has already been 25 years since Azerbaijan exposed to the unsettled conflict of Nagorno-Karabakh with Armenia. Armenia is still keeping the $20 \%$ of Azerbaijani territory under its occupation ignoring all the resolutions with mandatory legal force adopted since 1993 calling the armed forces back from the occupied regions immediately, completely and with no conditions. As a result, there are more than 1000000 refugees and forced immigrates in the country. Azerbaijan requires the fair and peaceful resolution of this conflict since long time and it is still aiding more than 640000 forced immigrates. The resolution of their exile problem, returning them to their own lands in a safe and peaceful conditions still remains very first priority of the government of Azerbaijan. Maintaining the sustainable economic development by the president Ilham Aliyev through the recent 14 years, decreasing the poverty, opening 1.6 million workplaces allowed to have some achievements on this field. 96 modern settlements have been built, more than 250000 refugee and forced immigrates have been provided with apartments. The poverty level of the forced immigrates have been reduced from $75 \%$ down to $12 \%$. In total, 6 billion USD was spent for addressing the social problems of the refugees and forced immigrates [9]. However, we think that the severity of the humanitarian situation of the forced immigrates makes necessary to have the international assistance to the national efforts. The full recovery of the human rights of the forced immigrates directly depends on the resolution of this conflict and for this purpose the activity of the UN and its human right mechanism have to be strengthened.

List of documents adopted by the United Nations on the Armenian-Azerbaijani conflict

Security Council resolutions

Security Council Resolution (S / RES / 822) - April 30, 1993

Security Council Resolution (S / RES / 853) - July 29, 1993

Security Council Resolution (S / RES / 874) - October 14, 1993

Security Council Resolution (S / RES / 884) - November 12, 1993

Security Council Chairman's declarations

Statement by the President of the Security Council (S / 23904) - May 12, 1992

Statement by the President of the Security Council (S / 24493) - August 26, 1992

Statement by the President of the Security Council (S / 24721) - October 27, 1992

Statement by the President of the Security Council (S / 25199) - January 29, 1993

Statement by the President of the Security Council (S / 25539) - April 06, 1993

Statement by the President of the Security Council (S / 26326) - August 18, 1993 
Statement by the President of the Security Council (S/PRST/1995/21) - April 26, 1995

GA resolutions

Emergency international assistance to internally displaced persons and refugees in Azerbaijan, 48/114 - 23 March 1994

Situation in the occupied territories of Azerbaijan, 60/285 - 15 September 2006

Situation in the occupied territories of Azerbaijan, 62/243 - 25 April 2008 [13].

But these decisions still remain on the paper and not implemented by Armenia.

Azerbaijan's position on this issue is unambiguous and completely transparent. All the occupied territory of Azerbaijan must be released and the right of refugees to return their own lands must be ensured. With this regards the government of Azerbaijan has prepared a comprehensive safe and secure repatriation plan for the refugees to return to their own lands called "Great return" together with the international organizations. After declaration of ceasefire on 1994 between the both sides the Armenian-Azerbaijan Nagorno Karabakh conflict has been recognized as a frozen conflict in international world. But this is not as it recognized. Through these years Armenia unilaterally violated the ceasefire lots of times. On April 2016 again by violating the ceasefire agreement Armenia fired Agdam and Tartar regions by using artillery intensively. As a result of that 34 Azerbaijani peaceful inhabitants were wounded, 6 inhabitants were killed including children, 232 houses were destroyed, public and private estates, as well as civilian infrastructure were seriously exposed to damage [10]. Armenian armed forces not satisfying with it intensively and intentionally fired Alkhanli village of Fizuly region by using heavy weapons on July 42017 and 2 years of child was killed together with his grandmother, on 7th of August 13 years old inhabitant of Tovuz region was seriously wounded. In fact this conflict is not frozen. Ceasefire violation every day and the targeting of the civilian population have become commonplace. In the recent years 34 Azerbaijani children were killed by Armenian aggressor army. In the 72th session of the UN GA by having a speech from the high tribune the president of Azerbaijan Republic announced to the world community the fair position of Azerbaijan based on the international law whose the territory remains under occupation for 25 years. The problem Azerbaijan faced is not only a problem of the region, it concerns to the whole world. By taking advantage of financial assistance of some donor countries and international organizations Armenia encourages the forced settlement of the Syrians with Armenian origin and the others in Karabakh region. That's why the world community must demonstrate more decisive and consecutive position on fair resolution of this conflict and must made Armenia to start working on the peace agreement. The main obstacle to solution of the problem is Armenia having a non constructive position, not showing respect to the resolutions of the UN SC, OSCE and EC. That's why long time efforts of OSCE's Mins Group remains unsuccessful who tries to achieve peaceful solution of the problem. All the decisions and resolutions adopted by international organizations mean strengthening Azerbaijan's position once again and confirmation of the solution of the problem on the bases of international principles of law. From this perspective, the speech of the president of Azerbaijan republic Ilham Aliyev in the 72th session of the UN GA once again shows strengthening our international positions and getting support by a range of international organizations to Azerbaijan.

In the same time, there is a statement of "The integrity of Azerbaijan shall never be subject to negotiations." Stated repeatedly and unequivocally by the president Ilham Aliyev, increased the hopes that the conflict will solved fairly maintaining the territorial 
integrity of our country: “...Armenian-Azerbaijan Nagorno-Karabakh conflict must be solved on the basis of international law, the UN SC resolutions, the territorial integrity of Azerbaijan must be fully restored."

Azerbaijan's position for the solution of the conflict remains unequivocal. The problem should be solved in the condition of ensuring the territorial integrity of Azerbaijan and within the internationally recognized borders of our country. This position bases on international law norms and principles, the UN charter, the final act of Helsinki and multiple international documents adopted on solution of this problem. In this perspective, 4 resolutions adopted by the UN SC, also decisions of OSCE, the Council of Europe and Islamic Cooperation Organization also are important and they are legal basis for defense of fair position of our country in the international level. The aim of the Minks group of OSCE established on March 1992 is to mediate the peaceful solution of Armenia-Azerbaijan Nagorno-Karabakh conflict: "From December 1996, the Minsk Group is co-chaired by three states - Russia, the United States and France. But unfortunately the conflict still remains unresolved. No ny progress have been achieved so far in the negotiation mediated by the Minsk group. Armenia is not interested in resolution of the conflict. He tends to keep the position of neither fire, nor peace [11]. But in the beginning of April 2016 as result of subversion of Armenian armed forces the tension in the contact line of troops which was followed by numerous human causalities once more confirmed that remaining the conflict frozen might always cause the intense war." But the international mediators for some reason don't demonstrate unequivocal position bout this case although they support the territorial integrity of Azerbaijan. We expect the cochairs of Minsk group of OSCE as well as world community to take a precise measures to solve this problem fairly. Failure to adhere to the principle of justice draws to crisis not only the region, but also the entire world.

It is long time since the Armenia-Azerbaijan Nagorno-Karabakh conflict has not been resolved. This conflict emerged as a result of Armenia's occupation of $20 \%$ of Azerbaijani lands. The UN has adopted 4 resolutions about this conflict. In these resolutions immediate removal of the invader from the occupied lands is required. However, for years, these UN documents have been dropped by Armenia as an unnecessary piece of paper. Despite that, the permanent members of the UN SC don't effectively require the invader to leave the occupied lands of Azerbaijan. It is interesting that, 3 members out of 5 of the Security Council are cochairs of the OSCE Minsk group which is dealing with the resolution of the conflict. It means that they are twice more responsible on resolution of the conflict. But what is the reality?

The reality is that, the USA, Russia and France doesn't put the aggressor in its place as a neither permanent member of the UN SC, nor as a cochair states. It is a painful and thought-provoking truth, but it is still the case. In such case a question arises, how come that the decisions of the UN SC about Iraq, Libya and Syria are immediately fulfilled but the decisions about Armenia remain ineffective? It leads to conclusion that the UN SC doesn't treat geopolitical problems fairly, discriminates between states. But in fact the UN has got effective influence mechanisms in such situations.

Azerbaijan always stresses the importance the following the relevant decisions of the SC and the principle to respect the states territorial integrity with regards to different matters related to the conflict between Azerbaijan and Armenia and calls for stopping the serious international crime acts doing unpunished committed through the conflict. The president Ilham Aliyev in his speech before the conference on the SC on May 42012 mentioned: "The ethnic cleaning policy of Azerbaijanis resulted in the occupation of $20 \%$ 
of internationally recognized territory of Azerbaijan and expelling more than 1 million people from their own lands. The SC has adopted 4 resolutions requiring the Armenian army to leave the occupied lands. But unfortunately it is already 20 years that Armenia ignores these resolutions" [12].

Azerbaijan always states the necessity to perform reforms in the organizations to reinforce the UN activity on solving the problems of mankind. Having note about the importance of the UN SC ability of demonstrating and adequate approach to prevent mutual misunderstandings between the member states in the current period where very complex processes are in progress in the international environment, in the 58th session of the UN GA on September 2003 Ilham Aliyev emphasized that the existing UN mechanisms did not meet the requirements of time and it made a necessary matter to to conduct reforms within the organization.

Azerbaijan proposed retreatment of the UN mechanisms, especially revising the veto right of the permanent members of the Security Council. Thus, Azerbaijan again brought the necessity of taking extra measures for achieving more effective actions for solving the existing problems and for increasing the role of the UN in international world to the agenda in the 59th session of the UN GA in September 2004. In the session the government head of Azerbaijan stated that: "The reformed Security Council must have a larger content, more responsible and democratic, it should have more transparent work methods and it should more operatively respond against the risks, threats and dangers of XXI century." Azerbaijan actively participates in reforms discussions within the UN, especially in the activity of the interstate negotiations group.

Development and cooperation are one of the UN's major goals. Reasonable scale of cooperation and development opportunities have been formed within the UN considering the rising welfare, preventing the wars and securing the peace and security. It is already the second decade that the development issues have been put into discussions in the UN high level discussions as a main goal and it was decided to achieve definite targets within the given period of time. In the UN summit in 2015 the decision was made about continuation of these efforts started on 2000 through the next 15 years (till 2030) and some targets on global development have been identified (169 targets on 17 "Sustainable Development Goal'). The UN promotes the international cooperation in this field by means of different agencies [13].

The president of Azerbaijan Ilham Aliyev, speaking in the 59th session of the UN GA held on September 2004 stated that the 4 resolutions of the UN SC about the Karabakh conflict was still not implemented and he stated it was necessary to prepare effective mechanisms to make them work [12]. The same time our leader stated that the reformed Security Council must have a larger content, more responsible and democratic, it should have more transparent work methods and it should more operatively respond against the risks, threats and dangers of XXI century.

On 29th October of the same year the matter of "The situation in the occupied lands of Azerbaijan" was included to the UN GA session agenda by the initiative of the delegation of Azerbaijan. Later on in the 98th plenary session of the 60th session of the UN GA held on September 7th 2006 and in the 86th plenary session of 62nd session on 14th of March 2008 the resolutions of "Situation in the occupied lands of Azerbaijan" have been adopted [13]. In these documents Armenians settlement in the lands of Azerbaijan, committing fires in those lands were condemned and unconditional withdrawal of Armenian armed troops from the occupied lands of Azerbaijan following the 4 resolutions of the UN SC were required. Along with that in these resolutions the 
respect to sovereignty of Azerbaijan and its territorial integrity have been expressed as well as the right of the expelled people to return to their own lands once again confirmed.

Azerbaijan accepts the UN to have an important role in maintaining the international peace and strengthening and maintaining the security as well as in the process of democratization. The same time official Baku supports the idea of performing the UN reforms in order to enable it to fight against the problems and threats concerning the world on XXI century.

\section{Література}

1. Azərbaycan tarixi: 7 cilddə, VII c. Baku: Elm, 2003. - 608 p.

2. Abdullayev Ә. Erməni təcavüzü, acı faktlar,fəlakətli nəticələr. / Elmi red.: M.Cəlilov; Azərbaycan Dövlət İqtisad Universiteti. - Bakı:İqtisad Unversitetinin Nəşriyyatı, 2003 - 114 p.

3. Erməni terroru-Armenian terror-Armyanskiy terror. / Đsir və itkin düşmüş, girov götürülmüş vətəndaşlarla əlaqədar Dövlət Kommisiyası. - n. y. y., n. i. y. Baku: Vətən, 2005. - 45 s.

4. Ohmədov E. Ermənistanın Azərbaycana təcavüzü və beynəlxalq təşkilatlar / E. Ohmədov. Baku, 1998. - $137 \mathrm{p}$.

5. Ohmədov E. Ermənistanın Azərbaycana təcavüzü və beynəlxalq təşkilatlar / E. Ohmədov. Baku, 1998. $-137 \mathrm{p}$.

6. Həsənov Ә. Azərbaycan və ATӘT: Ermənistan -Azərbaycan münaqişəsi və Dağlıq Qarabă̆ problemi ümumavropa təhlükəsizliyi fonunda / Ә.Həsənov. Baku, 1997. - 82 p.

7. Həsənov Ә. Müasir Beynəlxalq münasibətlər və Azərbaycanın Xarici Siyasəti / Ә.Həsənov. Dərslik. Baku. Azərnəşr, 2005. - 631 p.

8. Həsənov Ә. Azərbaycanın xarici siyasəti: Avropa dövlətləri və ABŞ (1991-1996). / Ә. Həsənov; elmi red. Ә. Mehdiyev. - Bak1 : Azərnəşr, 1998. - 315 p.

9. Huseynova H. Azərbaycan Avropa inteqrasiya prosesləri sistemində / H. Huseynova. - Bak1: Hərbi ədəbiyyat, 1998. - $280 \mathrm{~s}$.

10. Ibayev V. Ermənistan Azərbaycan münaqişəsi beynəlxalq hüququn JUS-COGENS prinsipləri prizmasında / V.Ibayev. - Bakı, "Çənlibel", 1999, - 128 s. Baku, 2001.

11. Ismayilov F. (2001) Qarabağ konflikti ABŞ-ın qlobal siyasəti konteksində / F. Ismayilov. -

12. Müasir dövrdə Beynəlxalq münasibətlər və Beynəlxalq hüququn bəzi problemləri (məqalələr toplusu). / AMEA Fəlsəfə və Hüquq İnstitutu. Beynəlxalq münasibətlər və beynəlxalq hüquq şöbəsi; red. İ. R. Məmmədzadə. - Bak1: Elm, 2014. - 368 s.

13. Azərbaycan və BMT münasibətləri [Electronic Resource]. - Mode of Access: http://mfa.gov.az/content/751 (last access: January 15, 2018). - Title from the Screen.

\section{References}

1. Azarbaycan tarixi: 7 cildda, VII c. (2003) Baku: Elm.

2. ABDULLAYEV, Ә. (2003) Erməni təcavüzü, act faktlar,fəlakətli nəticələr. Baku: İqtisad Unversitetinin Noşriyyatı.

3. Erməni terroru-Armenian terror-Armyanskiy terror. (2005) Baku: Vətən.

4. ӘНMӘDOV, E. (1998) Ermənistanin Azərbaycana təcavüzü və beynalxalq təşkilatlar. Baku.

5. ӘHMӘDOV, E. (1998) Ermənistanin Azarbaycana tacavüzü və beynalxalq taşkilatlar. Baku.

6. HӘSӘNOV, Ә. (1997) Azərbaycan və ATӘT: Ermənistan -Azərbaycan münaqişəsi və Dağlıq Qarabă̆ problemi ümumavropa tahlükasizliyi fonunda. Baku.

7. HӘSӘNOV, Ә. (2005) Müasir Beynalxalq münasibatlar va Azərbaycanın Xarici Siyasəti. Dərslik. Baku. Azərnəşr.

8. HӘSӘNOV, Ә. (1998) Azarbaycanın xarici siyasati: Avropa dövlatlari va ABŞ (1991-1996). Baku, Azərnəşr.

9. HÜSEYNOVA, H. (1998) Azarbaycan Avropa inteqrasiya proseslori sistemində. Baku.

10. İBAYEV, V. (1999) Ermanistan Azarbaycan münaqişəsi beynalxalq hüququn JUS-COGENS prinsiplari prizmasında. Baku, Çənlibel.

11. İSMAYILOV, F. (2001) Qarabağ konflikti ABŞ-ın qlobal siyasati konteksində. Baku.

12. Müasir dövrda Beynalxalq münasibətlar va Beynalxalq hüququn bəzi problemlari (maqalalar toplusu). (2014) Baku-Elm.

13. Azərbaycan və BMT münasibətləri [Online]. Available from: http://mfa.gov.az/content/751 [Accessed: January 15, 2018]. 
Фарахіле Бабаєва Шукурова, науковий співробітник, Відділ Кавказької політики Інституту Росії вивчення Кавказу, Азербайджанський національний університет

\title{
КАРАБАХСЬКИЙ КОНФЛІКТ В КОНТЕКСТІ ГЛОБАЛЬНОЇ ПОЛІТИКИ СПОЛУЧЕНИХ ШТАТІВ
}

\begin{abstract}
Анотація. Мета Мінської групи ОБСЄ, започаткована в березні 1992 року, полягає в посередництві мирному врегулюванню конфлікту між Вірменією та Азербайджаном в Нагорному Карабасі: «3 грудня 1996 року Мінську групу спільно очолюють три держави Росія, США та Франиія. На жаль, конфлікт все ще залишається невирішеним. Досі не було досягнуто прогресу в переговорах. Вірменія не зачікавлена у врегулюванні конфлікту. На початку квітня 2016 року внаслідок підриву збройних сил Вірменії напруженість на контактній лінії військ, щз супроводжувалася численними людськими втратами, ще раз підтвердила, щзо збереження конфлікту в замороженому стані може завжди викликати «інтенсивну війну». Міжнародні посередники чомусь не демонструють однозначної позииії у иіій справі, хоча вони підтримують територіальну иүілісність Азербайджану. Ми сподіваємось, щуо члени Мінської групи ОБСЄ, а також світова спільнота застосує необхідні заходи, щубб адекватно вирішувати и̧ю проблему. Недотримання принципу справедливості підводить до кризи не лише регіон, але і весь світ. Реальність полягає в тому, щуо США, Росія та Франція не ставлять агресора на його місие.
\end{abstract}

Ключові слова: конфлікт, США, ООН, ОБСЕ, політика. 